\title{
MIGRANTES NORDESTINAS E ESCOLARIZAÇÃO EM ITUIUTABA-MG (ANOS 1950-1960)
}

\author{
Sauloéber Tarsio de Souza \\ Universidade Federal de Uberlândia- CNPq \\ sauloeber@pontal.ufu.br \\ Daiane de Lima Soares Silveira \\ Universidade Federal de Uberlândia- CNPq \\ daianelss@hotmail.com
}

\section{RESUMO}

O presente texto tem como objetivo investigar a inserção e permanência das mulheres nordestinas no sistema escolar do município de Ituiutaba-MG, entre as décadas de 1950 e 1960. Nesse momento, a cidade recebia nordestinos que vinham dos estados do Rio Grande do Norte e da Paraíba, atrás das "oportunidades ilimitadas" geradas pelo ciclo econômico baseado na cultura de grãos (arroz, milho, etc), Ituiutaba foi denominada "Capital do Arroz". Nessas duas décadas a população passou de rural para urbana, e o sistema escolar deixou de ser majoritariamente privado com a multiplicação das escolas públicas. Assim, parte dos migrantes, sobretudo a segunda geração e, em geral as meninas (os meninos deveriam ajudar no sustento da família), transporiam os muros das novas instituições escolares, mesmo com todos os obstáculos em função de não portarem de forma plena e "legítima" os códigos culturais da região, sendo olhados com desconfiança. A partir dessa perspectiva, buscamos observar qual a relação estabelecida entre mineiros e nordestinas no interior das escolas, tentando visualizar a inserção desse grupo na nova dinâmica social que se submeteram a partir da decisão de migrar. Entendemos que a educação é fenômeno etnicizado (KREUTZ, 1998) e que, portanto, os confrontos refletidos no processo educacional são marcados pelas diferenças étnicas. Para a realização desse trabalho, utilizamos, sobretudo, do recurso a fonte oral.

Palavras-chave: Escolarização, Mulheres migrantes nordestinas, Ituiutaba-MG.

\section{NORTHEASTERN MIGRANT WOMEN AND SCHOOLING IN ITUIUTABA-MG (YEARS OF 1950-1960)}

\begin{abstract}
This paper aims to investigate the insertion and permanence of northeastern women at the city school system of Ituiutaba-MG, between 1950 and 1960. At this time, the city received northeasterns who came from the states of Rio Grande do Norte and Paraíba, looking for the "unlimited opportunities" generated by the business cycle based on the culture of grains (rice, maize, etc.), Ituiutaba was named "Capital of Rice". In these two decades the population changed from rural to urban, and the school system left of being mainly private with the multiplication of public schools. Thus, part of the migrants, especially the second generation, and in general the girls (boys should help to support the family), would transpose the walls of the new schools, even with all the obstacles on the basis of not possessing the cultural codes of this region, being regarded with suspicion. From this perspective, we observe the established relation between local people and the northeastern in the interior of the schools, trying to visualize the insertion of this group on the new social dynamics that they were submitted when they decided to migrate. We believe that
\end{abstract}


education is a ethnicized phenomenon (KREUTZ, 1998) and, therefore, the confrontations reflected in the educational process are marked by ethnic differences. To conduct this study, we mainly used the oral history.

Keywords: Schooling, northeastern migrant women, Ituiutaba-MG.

O presente estudo é resultado de pesquisa parcial sobre a escolarização de mulheres nordestinas que migraram para o Pontal do Triângulo Mineiro. Essa abordagem se deu a partir do projeto em desenvolvimento "Das Alagoas às Gerais: Migrantes Nordestinos e Escolarização no Pontal do Triângulo Mineiro (anos 1950 a 2000)" que tem como objetivo central estudar os fluxos migratórios nordestinos para o município de Ituiutaba e seus reflexos no sistema de ensino, apoiado pelo CNPq. Apresentamos aqui problematização inicial, enfocando as décadas de 1950 e 1960, quando buscamos analisar a "chegada das massas" à rede escolar local, com a progressiva elevação do acesso à escolarização, desencadeada, sobretudo, com os fenômenos da industrialização e urbanização desse período, tentando vislumbrar como se deu a inserção e permanência das mulheres migrantes nesses espaços institucionais.

Antes de observarmos nosso objeto, é preciso fazer referências aos fluxos migratórios e sua relação com a escola em geral. Entendemos que a migração deve ser estudada a partir do contexto de crescimento econômico da cidade, acelerado a partir da segunda metade do século XX, em função da expansão da cultura do arroz, como podemos ver pelo relato presente em revista comemorativa de fundação da cidade:

Antevendo o sucesso que poderia advir da cultura do arroz em terras tão férteis, o Sr. Antonio Baduy, distribuía aos fazendeiros locais, sementes selecionadas, estimulando a produção de tipo de melhor qualidade, tais como, amarelão e o pratão, hoje existente com abundância. (...) Assim é que de ano para ano, a produção foi aumentando, (...) Ituiutaba era o maior centro produtor de cereais de Minas (Centenário, 2001).

A indústria de beneficiamento atingiria seu auge na década de 1950, estimulando o desenvolvimento do município, de forma que também a rede escolar seria ampliada no mesmo período. Oliveira (2003) apontou a singularidade da história educacional da cidade, constatando o lento processo de institucionalização da escola pública em Ituiutaba no período que compreende os anos de 1908 e 1950. Nos anos de 1950, inicia-se a expansão dessas escolas que de apenas 02 passariam para 07 escolas estaduais, na década seguinte outras 08 escolas seriam criadas, de forma que no ano de 1970, a educação escolar na cidade era marcadamente pública (com 15 instituições de ensino), rompendo com o predomínio das instituições privadas e/ou confeccionais, que diminuiriam em números. ${ }^{1}$

Outro fator que demonstra o processo de intensas mudanças no município é o acelerado crescimento populacional urbano, o que também representa dado bastante relevante para a compreensão da articulação entre educação escolar e migração. Atentemos para as estatísticas abaixo:

Quadro 01 - População Rural e Urbana do Município de Ituiutaba

\begin{tabular}{|c|c|c|c|c|c|}
\hline ANO & População Rural & \% & População Urbana & \% & Totais \\
\hline 1940 & 30.696 & $88 \%$ & 4.356 & $12 \%$ & 35.052 \\
\hline 1950 & 43.127 & $81 \%$ & 10.113 & $19 \%$ & 53.240 \\
\hline 1960 & 39.488 & $55 \%$ & 31.516 & $45 \%$ & 71.004 \\
\hline 1970 & 17.542 & $27 \%$ & 47.114 & $73 \%$ & $64.656^{2}$ \\
\hline
\end{tabular}

Fonte: Fundação IBGE - Censos Demográficos dos anos de 1940 a 1970. 
O expressivo crescimento populacional demonstrado acima pode ser creditado a alta taxa de natalidade que era superior a de mortalidade, mas como vemos também, foi resultado da migração rural, pois neste momento, significativa parcela da população brasileira se deslocava do campo para as cidades em busca de melhores condições de vida (saúde, moradia e educação), com perspectiva de empregabilidade no comércio e setor de serviços públicos que se expandiam com velocidade, acompanhando o desenvolvimento nacional. A tabela demonstra essa inversão da relação rural e urbano no município de Ituiutaba, ou seja, em três décadas a população passou de predominantemente rural para urbana, nesse mesmo período, o sistema escolar deixa de ser majoritariamente privado tornando-se marcadamente público.

Os impulsos modernizantes no município eram perceptíveis em outros setores além do econômico e educacional. Nos anos de 1950, o poder público do município preocupouse com o Plano Urbanístico, com ampliação dos serviços de abastecimento de água e de iluminação pública, arborização e calçamento de ruas, construção de prédios públicos, buscando atender às demandas da população que se avolumava. $\mathrm{Na}$ década seguinte, a mudança urbanística acelerou-se ainda mais, com a chegada do asfalto, a construção de praças, implantação do Distrito Industrial e do primeiro Campus Universitário no município (CORTES, 2001).

É a partir desse contexto que buscamos estudar os fluxos migratórios e sua relação com a rede escolar pública em Ituiutaba, voltando o olhar para a escolarização da mulher migrante. Investigamos as representações sociais elaboradas em torno desse grupo, revelando o processo histórico-educativo vivido pela região, abrindo novas perspectivas para a compreensão do processo de modernizaçãa $o^{3}$ local, apontando os migrantes como fator importante nesse movimento, certamente, uma das especificidades da região.

A migração para o pontal mineiro era motivada por notícias em rádios e jornais por todo o país que difundiam a idéia de "novo eldorado" nos anos de 1950, mas também pelos recados enviados por parentes e amigos dos primeiros migrantes que chegaram à região para o trabalho na lavoura, o que deu início a atividade do "agenciador de mão-de-obra" responsável pela intermediação entre fazendeiros e trabalhadores. ${ }^{4}$ Os nordestinos "Espalharam-se por essa vasta região trazendo seu modo de vida, sua linguagem, estabelecendo diferenças, que deram origem a interpretações variadas, gerando explicações, conceitos e preconceitos." Chegando ao pontal, eram chamados de “'nortistas', 'pau-de-arara', 'barriga-verde', 'caicó"”, com seus hábitos e costumes e com o uso da "peixeira" na cintura, delineou-se um perfil de gente violenta que deveria ser tratada com cautela e mantida a distância (SILVA, 1997, p.8-9). ${ }^{5}$

É preciso reconhecer que a presença dos nordestinos no município foi marcante e decisiva no processo de desenvolvimento econômico nesse período, muito embora, essa participação tenha sido pouco observada, mantendo-se praticamente invisível por décadas, como apontou Silva (1997, p.127): "O 'eldorado' que atraiu muitos trabalhadores nordestinos, ainda na década de 40 , foi em grande parte construído por eles."

O perfil do migrante foi assim definido: “(...) a maioria dos nordestinos que para aqui vieram, eram pessoas simples, analfabetas, de costumes e hábitos rudes e que habitavam o interior do Rio Grande do Norte e da Paraíba."(SILVA, 1997, p.133) Muitos deles migravam sem informação alguma sobre seu destino, as condições de vida e de trabalho que os esperavam: "Assim como não escolhiam o patrão, também não escolhiam o tipo de serviço que iam executar. O destino do sujeito só era conhecido quando chegava na fazenda e começava a trabalhar." 6 Além disso, o trabalho que lhe era reservado era bastante pesado, atividade que pouco interessava à população local: "Arrancar tocos foi a 
tarefa da maioria dos nordestinos que chegaram primeiro à região. Esse tipo de trabalho era extremamente árduo." (SILVA, 1997, p.72-73)

Nos anos de 1950 e 1960 o acesso a educação pública começava a se expandir, de forma que parte desses migrantes, sobretudo a segunda geração - os filhos dos pioneiros, transporia os muros das novas instituições escolares que se multiplicavam pelos bairros da cidade, mesmo com todos os obstáculos e dificuldades em função de não portarem de forma plena e "legítima" os códigos culturais da região. Por isso também, eram olhados com certa desconfiança já que dividiam o espaço do mineiro, buscando as oportunidades de trabalho, além da expectativa de acesso a serviços públicos que desconheciam no seu local de origem, tais como saúde e educação. ${ }^{7}$

A taxa de analfabetismo dos estados do Nordeste em 1950 estava em torno de $70 \%$ da população acima de 10 anos (considerando-se as crianças acima de 05 anos essa taxa atingiria 75\%), enquanto nos estados do Sudeste esse número representava $45 \%$. No entanto, Ituiutaba, apesar de estar localizada geograficamente nessa região, apresentava número próximo ao da região centro-oeste com $57 \%$ de sua população não alfabetizada, um pouco acima da média nacional de 55\% (Recenseamento, IBGE, 1950).

Portanto, o migrante que para a região do pontal se deslocava não era alfabetizado, dado que surgiu nas entrevistas realizadas por Silva (1997, p.85), vejamos:

Punham a juro com os fazendeiros, juro barato sabe, porque naquele tempo num usava por no Banco, também muitos nem sabiam escrever. E ainda: (...) mas era um pessoal muito bom, são assim..., vinha muita gente analfabeta, quase igual a eu mesmo, mas muito educado, muito humilde, muito fácil de trabalhar com eles, não me deram problema, esses 11 anos que eu tive a pensão São Pedro eu nunca tive problema com hospede que viesse no caminhão de pau-de-arara. \{Depoimento de ex-dona de pensão\} (SILVA, 1997, p.114)

Até fins dos anos de 1960 o acesso a escola era mais restrito a mulher do que aos homens, no nordeste, o analfabetismo era cerca de $30 \%$ maior entre elas do que entre eles (IBGE, 1960). Contudo, essa situação começou a ser alterada com o fenômeno da urbanização, o que refletiria na forma de inserção e permanência no sistema escolar das filhas dos migrantes, nascidas no nordeste ou na região do pontal mineiro.

Eleger as mulheres migrantes como objeto desse estudo, tem relação com a pouca visibilidade da presença das nordestinas no município, já que os trabalhos existentes sobre migração, como vimos antes, priorizaram o trabalhador rural, em geral homens por representar a maior parte dos migrantes. A partir do final da década de 1980, o estudo e análise da categoria gênero ganharia importância para as ciências sociais, a história também assumiria esse desafio de investigar o gênero como um aspecto determinante das práticas sociais de homens e mulheres na sociedade.

A história não ficou à parte do movimento feminista. Aos poucos, o sexismo, imperante na historiografia de até meados do século XX, foi sendo substituído pela exigência de que se deveria levar em conta os sexos ao se fazer história. (LOPES e GALVÃO apud SIMÕES, 2006)

Dessa forma, estudar a escolarização das migrantes nordestinas em Ituiutaba-MG, permite-nos refletir sobre o papel social desse grupo de mulheres, colaborando para o desvelamento da história sobre o feminino na região do pontal. No grupo de sete migrantes entrevistadas deparamo-nos com relatos marcados pelo preconceito étnico, uma 
dificuldade que incomodou e ainda incomoda algumas das depoentes. Na inserção dessas jovens nas escolas, observamos o encontro cultural repleto não apenas de violência simbólica, mas também física como elemento constituinte do comportamento escolar desse grupo, pois a agressão de que era alvo era revidada com a mesma intensidade, buscando estabelecer seu espaço, como veremos a frente.

Nesta pesquisa, procuramos trabalhar na perspectiva da diversidade de fontes, observando-se a complementaridade entre elas, utilizamos além dos depoimentos, os documentos impressos e iconográficos. ${ }^{8}$ De acordo com Demartini (2008, p.03):

(...), a complementaridade entre as fontes já existe na própria construção dos documentos orais, seja antecedendo-os com questões que suscita, seja deles resultando, pelo processo de interação entre pesquisador/pesquisado que permite a exposição e utilização do que ficou guardado, ou, muitas vezes, até esquecido.

Nesse tipo de pesquisa, onde o objeto da investigação está encoberto pela rigidez das relações sociais, deparamo-nos com dificuldades diversas, mas nenhuma é tão relevante quanto a que diz respeito ao acesso à documentação nas repartições públicas e unidades escolares. Uma das formas de superação deste obstáculo é a utilização de fontes orais e escritas (jornais) que se referiam à presença do nordestino na cidade, sendo bastante importantes em nosso trabalho para "identificar o modo como (...) uma determinada 'realidade' social é construída, pensada, dada a ler". (CHARTIER, 1990, p.15) ${ }^{9}$

Pelos depoimentos colhidos, compartilhamos com Silva (1997) a idéia de que existia diferenciação entre os próprios migrantes em função de sua origem social, uma pequena parte, acreditamos, migrou em condições melhores, isso se refletiu no acesso e permanência na escola, de forma que algumas delas frequentaram instituições privadas e tradicionais da cidade, como vemos nesse excerto de entrevista ${ }^{10}$ :

Tinha aquela história, era quatro, três pagava, uma não pagava e mamãe foi trabalhando e pagando nosso estudo. Então nós estudamos a vida inteira em escola particular que era o Santa Tereza, uma escola de freira. (...) Fiquei um ano no Marden, mas eu não me adaptei com a escola, aí fui lá pro Machado de Assis. Aí lá eu fiz o segundo grau. (...) Nessa chegada minha, quando você vai pra uma escola que é de um nível aquisitivo alto, e também por você ser um migrante, havia uma pequena rejeição das pessoas em cima da gente. Então o nordestino era visto como um intruso nessa época. Então assim, o povo te olhava meio assim,... você se sentia um pouco assim de lado, entendeu. Até as pessoas adaptarem com você, te aceitar. eu acho que a gente... Eu sofri um pouco com isso. Entendeu, havia rejeição do mineiro em cima do nordestino. Mas o povo vendo o valor que é o povo da minha terra, eles começaram a aceitar. (Entrevista C, março/2010)

Essa família veio em condição bastante diferenciada da maioria dos migrantes, pois era uma exceção. Na fala da maioria das entrevistadas, ao chegarem à região do pontal, viviam em situações muito difíceis e precárias, suas casas eram de pau-a-pique e o piso de terra batida.

A minha casa era de terra, chão batido. O fogão era de barro. A casa era de chão e as paredes era de pau. Não era de taboa não. Era de pau, pau mesmo. Pau enfiado no chão. (...) E a nossa casa, o chão, era aguado, nós aguava quase todo dia pra ficar bem... Não tinha uma terrinha. Era chão 
batidim, batidim, batidim, que a gente podia andar até descalço. (Entrevista F, abril/2010)

Em alguns casos a situação era pior, como vimos no relato do pai de uma das entrevistadas, presente em um momento da entrevista, narrando a chegada à cidade com sua família (esposa e filhos), revelando ferida não cicatrizada, em função das circunstâncias a que foram submetidos: "Chegou na fazenda, abriram as porteira e vocês entraram e foi lá pra dentro do currá..." (Entrevista E, abril/2010) Na rememoração desse fato, ele viu apenas a sua família entrando no curral, como se ele não estivesse presente, pois o pior era ver os seus familiares em tal condição. Portanto, para essas famílias a condição social jamais permitiria que colocassem suas filhas em escolas particulares. $\mathrm{O}$ acesso a escola se dava nas próprias fazendas em situação também precária, em salas multi-seriadas, sem infra-estrutura alguma. Em um dos depoimentos, a colaboradora assim descreveu a escola da fazenda em que estudou:

E era uma escola só, uma professora só. E a professora..., que a professora era prima do papai. Então, foi essa a escola. E lá... E Lúcia foi pequenininha. Lúcia não tinha idade, mas ela queria tanto ir, que ela... que a professora falou: Não, deixa ela ir. (...) Ia a pé. Ia a pé. Às vezes, depois de bicicleta. De a pé enfrentando as vacas no meio do... da estrada que tinha vaca. (...) Uma professora pra quarenta alunos, por aí assim. Eram poucos os migrantes. Era mais já, os que eram daqui mesmo. Poucos os migrantes. (Entrevista A, fevereiro/2010)

Em outro depoimento, a colaboradora falou das dificuldades de educação na zona rural: "Porque nessa época não tinha escola nas fazendas. Ih, era a coisa mais difícil do mundo escola em fazenda. Só esse povo que podia mesmo é que vinha pra cidade estudar, né. Quem os pais sabia, ensinava em casa, mas meus pais também não sabia." Ela só estudaria quando se transferiu para a cidade, em escola particular chamada Santa Terezinha (foto) que era improvisada em uma casa, mas pelos custos da educação só se manteve na escola por um ano, essa instituição se localizava: "Na Vinte, na esquina da Dezenove. Hoje ta... desmancharam a casa lá. Tinha quintal, tinha um pátio de brincar, tudo. (...) Ah, eu fiz só o quarto ano e mais nada" (Entrevista B, fevereiro/2010)

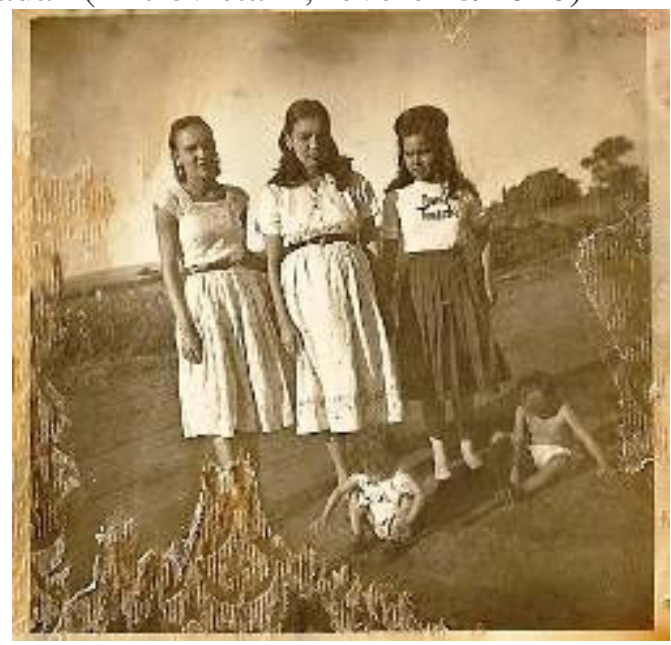

Fonte: Acervo particular depoente B (com o uniforme escolar e a direita na foto). 
Apesar de algumas famílias terem condições de inserir suas fillhas nas instituições particulares da cidade a permanência delas não era tranqüila, e as referências a discriminação e a punição "do diferente" surgem em todas as falas:

Não, pra você ter uma idéia, não tinha um dia que a Irmã Letícia não me botava de castigo e não me chamava pra ir lá na frente. Ela chegava... Eu já ia andando pra frente. É eu que ela vai chamar. E era. Nossa! Eu era muito levada. Entrava na clausura das freiras pra ver as freiras sem aquele véu. Entrava no confessionário. Nossa, eu fazia miséria naquele Santa Tereza. Descia aqueles escorregador das escadas, sabe assim. Correndo, assim, escorregando. Subia nas árvores, nas últimas árvores. Subia em cima da mesa de pingue-pongue. (Entrevista C, março/2010)

Os conflitos não ficavam apenas no campo da discriminação, mas chegavam aos embates físicos: "Tanto que uma vez, eu não sei o que aconteceu, eu dei uma briga na escola, eu bati em seis menina lá. Eu rodava minha lancheirinha e, vem, vem, vem, vem! E o povo vinha e a lancheirinha batia." (Entrevista C, março/2010) E outra depoente que estudou em escola rural assim afirmou: "Eu era meia brava (risos). Sempre pegava uma briga na escola (muitos risos). Eu era meia brava." (Entrevista A, fevereiro/2010) Esses trechos denotam que no novo universo (a escola) que se abriu a alguns migrantes e seus filhos, teve início um comportamento local que instituiu o outro, ou o diferente, como o "não é" ou aquele "que é", negando ou afirmando a alteridade ao atribuir-lhe valores negativos ou positivos quanto às suas características regionais, físicas, e até mesmo emocionais (LÉVINAS, 1997). Assim, o preconceito em relação ao povo nordestino e seus costumes foi gradativamente instituído. ${ }^{11}$

Nesse sentido, observa-se o preconceito a que foram submetidos e que afetava não só a interação professor-aluno ${ }^{12}$, mas também o comportamento entre os próprios colegas da escola. A discriminação, muitas vezes associada a agressão física, levava as alunas a represálias do mesmo gênero, o que entendemos ser a forma de como encontraram para estabelecer seu espaço frente a nova situação. Nesse depoimento podemos ver um pouco mais do estabelecimento dessa relação discriminatória em relação ao comportamento cultural do migrante:

Mas porque que nós brigava? (...) era cada brigas horrorosas, de esquina, de correr, de tudo quanto era trem. Nós andava armado. Nós andava... Era uma gangue armada. (risos) Eu conto as arma que nós tinha. Nós tinha porrete, tudo escondido. Nós apanhava muito por causa da nossas violências. (...) Mas é porque? Porque nós chegava... Nós, naquela época, chamar de nortista era xingar... Era chegar e eles ficava: 'nortista, não sei o que'... Aí nós falava: Deixa! Aí se fazia alguma coisa: 'Foi aquela nortista! Foi as nortista!' Tudo que acontecia nas escola, era os capeta do nortista! Aí os nortista era revoltado. (Entrevista F, abril/2010)

A formação social e histórica da identidade tem estreita relação com as interações que acontecem em sala de aula (OLIVEIRA, 2007). Sendo assim, o preconceito étnico que as migrantes eram acometidas influenciava em sua formação de maneira determinante, como podemos ver nesse relato de uma depoente ao ser perguntada sobre sua condição de nordestina:

Porque quando eu fiz a quarta série na fazenda com o professor José Gonçalves, ele tinha pavor de nordestino. (...)E aí depois que eu vim estudar, fazer a quinta série na cidade, eu tive um professor que se 
chamava Artur Machado Magnino. E um dia ele falou muito importante sobre o nordestino. Sobre as coisas... Aí aquilo me tocou. Aí eu comecei a tomar gosto pelo nordestino e fui incentivando outros nordestino e hoje o meu desgosto é não ter nascido lá. (...) Mas a gente, todos nós tinha muita vergonha de ser nordestino porque todo mundo falando, falando, falando, uai. Não é? Nós tinha vergonha mesmo, não é? (Entrevista $F$, abril/2010)

Constatamos que os primeiros grupos migrantes tinham pouco acesso a escolarização já que até mesmo para a população local, a escola era ainda uma "dádiva das classes privilegiadas" às classes menos favorecidas (Folha de Ituiutaba, 1963). Mas a partir da segunda metade da década de 1960 esse quadro mudaria de figura, pois os migrantes começaram a se transferir para a cidade: "Aos poucos, muitos foram deixando as fazendas em busca da cidade e do estudo para os filhos e depois, com a crise na agricultura, provocada pelas estiagens no final dos anos 60 e início de 70". (SILVA, 1997, p.101) Até esse período, a maior parte deles estava nas fazendas que não contava com número de escolas adequado para o atendimento a toda a população da zona rural:

Embora a população rural fosse superior à urbana nos anos 50, não era em todas as regiões que existiam escolas. Se alguns patrões se ocupavam em providenciar escola e professores para os filhos e estendiam esse privilégio aos filhos dos agregados, isso, definitivamente, não era regra geral. Muitos fazendeiros traziam professores para dentro de suas casas, exclusivamente, para a instrução dos próprios filhos. Dona Marlúcia foi professora de uma escola, nos anos 52/53, criada pelo fazendeiro, dono da fazenda onde o pai arrendava um pedaço de terra. As crianças estudavam de manhã e à noite ela alfabetizava os adultos, mas esses 'queriam só aprender a assinar o nome, depois que assinava o nome ninguém queria mais nada'. (SILVA, 1997, p.101-102)

Ao longo dos anos de 1960 os fluxos migratórios começaram a ter o meio urbano como destino final, surgindo, em 1961 a Associação da Colônia Nordestina, "entidade que visa defender os interesses dos emigrantes nordestinos neste município" (SILVA, 1997, p.107), pela iniciativa de Cristovam Jose Ribamar Nunes, que buscava ajudar nordestinos sem documentação, e pela sua atuação juntos a eles, elegeu-se vereador no ano de 1962. Os migrantes ganharam pouco a pouco visibilidade social, construindo seus espaços de convívio. A escola passaria a ser local para a produção e reprodução da cultura do migrante. Segundo Kreutz (1998), o étnico é elemento de diferenciação social, influi na percepção e na organização da vida social o que significa que a educação é etnicizada, "atravessada" pela etnia:

Eleger a etnia como uma das categorias em educação significa entender que o pertencimento étnico, enquanto uma concreção ou singularização do cultural numa especificidade própria, tem uma dimensão engrendradora das potencialidades específicas de grupos no conjunto do processo histórico. (KREUTZ, 1998)

A partir dessa perspectiva as diferenças culturais seriam as novas barreiras impostas aos nordestinos para permanecerem nas instituições, a partir dos anos de 1970 quando o acesso a educação passou a abranger de forma ampla o grupo migrante em Ituiutaba. 
Apesar da expansão das escolas públicas, tal processo ocorreu de forma bastante precária, de maneira que a permanência na escola continuava sendo privilégios de poucos, um dos fatores para isso seria a precariedade da rede escolar pública, apontada pelos jornais locais, como podemos ver abaixo:

O Grupo Escolar João Pinheiro - A Esperada Reforma do seu Prédio (Folha de Ituitutaba, 28-out-1950) Dois anos depois, com a participação do governo municipal é que a reforma dessa escola aconteceria: Ampla colaboração da prefeitura na execução de obras do Estado. (Folha de Ituiutaba, 27-dez-1952) 13

Os obstáculos para as migrantes se manterem nas escolas eram maiores em função das dificuldades cotidianas decorrentes de sua condição social, mas acentuadas pelas diferenças culturais. Nesse depoimento, a colaboradora que estudou em escola pública estadual abordou alguns desses aspectos:

Então eu ficava puxando a água pra encher as vasilhas assim, até encher. Quando dava o sinal lá na escola é que eu saía correndo pra ir pra escola. Era desse jeito. Minha vida sempre foi sacrificada... desde pequena. (mostrou-se emocionada). (...) Assim, do Ensino Fundamental. Deu pra mim aprender a ler e a escrever. Sabe, assim muito mal, engolindo muitas letras, mas deu. Eu fiquei assim até os cinqüenta anos, quando eu resolvi estudar de novo. (Entrevista D, fevereiro/2010)

Em princípio, o que salta aos olhos neste estudo é o preconceito construído e reproduzido pela comunidade em relação a população migrante, mas em especial a mulher jovem nordestina que se inseria no espaço escolar. A cidade, arraigada às tradições de seu povo, tem reforçado a valoração negativa atribuída às características da alteridade: o nordestino. Tal atitude é demonstrada nas falas dos indivíduos, em veículos de comunicação de massa, implicando na negação do diferente e, no mesmo movimento, a afirmação da própria identidade como superior/dominante. Uma população que padece de problemas comuns não se identifica entre seus membros, tendo como barreira quase intransponível, o sotaque nordestino, supostamente colocando os miseráveis mineiros em posição superior, relativamente aos miseráveis nordestinos. Vimos por alguns depoimentos que nas escolas, esse encontro de culturas gerou situações diversas e conflituosas frente à cultura migrante que portava a expectativa de melhoria de vida na região imaginada como o "Eldorado", terra da fartura e abundância, mas que se torna realidade a partir da decisão de migrar.

Outro reflexo esperado junto ao grupo migrante trata-se de lutar contra uma autoidentificação negativa, mudando os valores, transmudando as características ditas vergonhosas em características que orgulham, promovendo o início do fim da dialética do amo e do escravo, ao menos no que diz respeito ao preconceito frente aos nordestinos, levando-os a definirem seus próprios valores sociais. A instituição de novos valores como normas e novas figuras jurídicas que permitem mencionar e punir o preconceito abrem o caminho para a expansão de uma nova realidade social. As interdições lingüísticas no mundo escolar, especialmente no encontro de culturas decorrente da migração, podem apagar a singularidade histórica, social, cultural e moral dos indivíduos. Desse ponto de vista, é preciso avançar na garantia dos direitos de grupos minoritários, reconhecendo-se o outro, o diferente não apenas como objeto, mas como sujeito social. (GOFFMAN, 1998). 14 
No que diz respeito às condições sociais das mulheres migrantes, ficou claro que além das dificuldades com a discriminação étnica, para prover a casa, os pais contavam com a ajuda ativa das filhas. Apesar de uma vida sofrida, com muito trabalho na fazenda ${ }^{15}$, elas estudaram e algumas, mesmo com muitos obstáculos, terminaram a graduação. Pensar a migração a partir da mulher nordestina na região, colabora para melhor compreensão acerca das diversidades étnica, cultural e de gênero, ainda que aqui priorizamos esse último aspecto.

Segundo Carneiro (2002) "A emergência desses novos atores decorre da insuficiência da perspectiva universalista para contemplar as diferentes identidades sociais e realizar um dos fundamentos da democracia, que é o princípio de igualdade para todos". Dessa forma, percebe-se uma necessidade premente de dar voz às minorias que durante muito tempo ficaram silenciadas nas instituições oficiais e nos estudos e pesquisas da História e História da Educação e de outras ciências humanas. É preciso entender que a escola sempre foi vista de forma diferente entre meninos e meninas, sendo importante revelar as distinções entre seus olhares.

\section{REFERÊNCIAS}

BAUMAN, Z. Confiança e medo na cidade. Rio de Janeiro: Zahar, 2009.

BENEVIDES, M. V. M. O governo Kubitschek: desenvolvimento econômico e estabilidade política. Rio de Janeiro: Paz e Terra, 1976.

BURKE, Peter. A violência das mínimas diferenças. Folha de S.Paulo, 21 maio 2000. Caderno Mais!, p. 25.

CANCLINI, Nestor G. Culturas Híbridas. Estratégias para entrar y salir de La modernidade. Buenos Aires: Editorial Paidós, 2001.

CARNEIRO, Sueli. Por um multiculturalismo democrático. TV Brasil, 2002. Programa Salto para o Futuro.

CHARTIER, Roger A história cultural: entre práticas e representações. Trad.Maria M.de Galhardo, Lisboa: Difel (85), Rio: Bertrand Brasil, 1990.

CORTEZ, Carmen D.C. Ituiutaba Conta a sua História. Ituiutaba, EGIL, 2001.

DEMARTINI, Z.de B. F. Pesquisa histórico-sociológica, imigração e educação: as fontes e sua análise. Anais VII Congresso Luso-Brasileiro de História da Educação, Porto, 2008.

DUSSEL, Enrique. 1492 o encobrimento do outro: a origem do "mito da modernidade". Petrópolis: Vozes, 1993.

ELIAS, Norbert. Os estabelecidos e os Outsiders. Sociologia das relações de poder a partir de uma pequena comunidade. Rio de Janeiro, Zahar: 2000.

GERMANO, José W. Estado Militar e Educação no Brasil (1964-1985). São Paulo: Cortez, 1993.

GIROUX, Henry A. Praticando estudos culturais nas faculdades de educação. In SILVA, Tomaz T. da - Alienígenas na sala de aula: uma introdução aos estudos culturais na educação. Petrópolis: Vozes, 1995.

GOFFMAN, Erving. Estigma: notas sobre a manipulação da identidade deteriorada. Rio de Janeiro: Guanabara, 1988. 
GRUZINSKI, Serge. O Pensamento Mestiço. São Paulo: Cia das Letras, 2001.

HALL, Stuart. Da Diáspora. Identidades e mediações culturais. Belo Horizonte: Ed. UFMG, 2003.

KREUTZ, L. Identidade Étnica e Processo Escolar. Anais XXII ANPOCS, Caxambu, 1998. . "Migrações e Culturas em Diálogo". In FELGUEIRAS, M.L. e VIEIRA C.E. (orgs.) Cultura Escolar, Migrações e Cidadania. Porto: Soc.Port.Ciências da Educ., 2010.

LÉVINAS, Emmanuel. Entre nós: ensaios sobre a alteridade. Petrópolis: Vozes, 1997.

LOURO, Guacira L.- “A História (oral) da Educação: Algumas Reflexões” in Revista Em Aberto - "Ensino de História" - ano IX, no.47, 1990.

OLIVEIRA, L.H.M.M. História e Memória Educacional: o papel do colégio Santa Teresa no processo escolar de Ituiutaba, no Triângulo Mineiro-MG (1939-1942). Dissertação de Mestrado - Universidade Federal de Uberlândia, 2003.

OLIVEIRA, I. M. de. Preconceito e Autoconceito: identidade e interação na sala de aula. Campinas-SP: Papirus, 2007.

RIBEIRO, Paulo R. M. "História da Educação Escolar no Brasil: Notas para uma Reflexão" in Revista Paidéia- Cadernos de Educação. USP, no.4, 1993.

SANTOS, Boaventura de Souza. Uma concepção multicultural dos direitos humanos. Lua Nova, n. 39, 1997.

SILVA, Dalva M.de O. Memória: Lembrança e Esquecimento. Trabalhadores Nordestinos no Pontal do Triângulo Mineiro (Décadas de 1950 e 1960). Dissertação de Mestrado: PUC-SP. 1997.

SILVA, Tomaz Tadeu da (Org.). Identidade e diferença: a perspectiva dos estudos culturais. Petrópolis: Editora Vozes, 2000.

SIMÕES, Renata Duarte. Gênero, Educação e Educação Física: um olhar sobre a produção teórica brasileira. 29ª Reunião Anual da Anped. GT23. Caxambu-MG, 2006. Disponível em: <http://www.anped.org.br/reunioes/29ra/trabalhos/trabalho/GT23-2377-Int.pdf $>$.

\section{FONTES}

- ENTREVISTAS:

$\Rightarrow$ A - migrou em 1952, vindo de Caicó-RN, era criança;

$\Rightarrow$ B - migrou em 1944, vindo de Santana de Matos-RN;

$\Rightarrow$ C - migrou em 1950, vindo de São Vicente-RN na primeira infância.

$\Rightarrow \mathrm{D}$ - filha de migrantes que vieram nos anos de 1950.

$\Rightarrow E$ - migrou em 1953, vinda de Florânia-RN.

$\Rightarrow$ F - filha de migrantes que vieram nos anos de 1954.

- JORNAIS/REVSITAS: Consulta as Coleções dos seguintes jornais: "Folha de Ituiutaba", "Gazeta de Ituiutaba", "Correio do Pontal", "Correio do Triângulo", "Cidade de Ituiutaba" e "Município de Ituiutaba", constantes do acervo da Fundação Cultural de Ituiutaba. Revista O Centenário de Ituiutaba, 2001. 
- SUPERINTÊNCIA REGIONAL DE ENSINO: Consulta aos arquivos oficiais e estatísticas educacionais do município.

- INSTITUTO BRASILEIRO DE GEOGRAFIA E ESTATÍSTICA: Recenseamentos de 1940, 1950, 1960 e 1970.

\section{NOTAS}

${ }^{1}$ Não fizemos referencias as escolas rurais municipais que eram freqüentemente criadas e extintas, com vida efêmera e pouca estrutura (salas multiseriadas, professores leigos, poucos alunos, alta evasão e repetência) Fonte: Superintendência Regional de Ensino - Ituiutaba-MG, 2010.

${ }^{2}$ O decréscimo populacional entre os anos de 1960 e 1970 decorreu da emancipação política de alguns distritos administrados pelo município de Ituiutaba, mesmo assim, o movimento de urbanização fica bastante evidenciado.

${ }^{3}$ A modernização verificada no país manteve-se, principalmente, no âmbito da consolidação dos mercados de massa e na sofisticação do consumo, tendência acentuada em todo o mundo, após a Segunda Guerra, que gerou imenso salto tecnológico permitindo incremento substancial na produção industrial (VIANNA, 1997).

${ }^{4}$ Segundo Silva (1997), um dos pontos de ligação entre a região do pontal mineiro e o Nordeste estaria na atividade do garimpo no Rio Tejuco nos anos de 1930, trazendo os migrantes pioneiros para a região. Nos anos de 1950 e 60, as excursões para o nordeste, organizadas por donos de pensões e agenciadores, trariam migrantes em massa para Ituiutaba.

5 Tal imagem também era reforçada pelos jornais locais: "Não encontramos com freqüência o migrante nordestino nas páginas dos jornais, com exceção de algumas notícias sobre a seca no Nordeste, breves notas sobre a sua Associação, artigos denunciando o tráfico de trabalhadores ou nas colunas policiais." (SILVA, 1997, p.16)

${ }^{6}$ Freqüentemente, o agenciador prometia: “(...) um salário maior do que realmente era praticado na região ou condições de vida e moradia que nem sempre correspondia à realidade.” (SILVA, 1997, p.32)

${ }^{7}$ Esses anseios muitas vezes ficavam no campo do desejo, como vemos nos comentários de Silva (1997, p.44-45) a partir de um depoimento de migrante: "Apesar das precárias condições de vida oferecidas pelo patrão ele não pareceu se importar. Além do rádio, o chaveiro e a caneta esferográfica que comprou, embora não tivesse chaves e nem soubesse escrever, parecia dar a ele uma ilusão de prosperidade. (...) O chaveiro e a caneta esferográfica talvez simbolizassem um sonho secreto de um dia ter chaves e poder escrever."

${ }^{8}$ Nossa expectativa é no sentido de dar voz aos grupos sociais pouco "visíveis", denunciando a estratificação e o conflito social, priorizando nesse trabalho as manifestações das mulheres anônimas, aqui em específico, as jovens nordestinas no Pontal do Triângulo Mineiro. Acreditamos poder estimular a construção de identidades positivas em relação a elas alvos de preconceito, e também poder implementar formas novas de resolução de conflitos com a participação ativa dos grupos sociais interessados. O preconceito, em suas múltiplas manifestações, é pernicioso e impede a integração universalista, transformando os valores humanos em fatos arbitrários que exprimem a força vital da raça, da classe, do gênero, ou outra qualquer. $O$ distanciamento social promovido pela regulação dos comportamentos sociais e individuais não pacificou os relacionamentos, ao contrário, conduziu a uma racionalização do diferente que derivou em construções preconceituosas e violentas das diferenças, desumanizando-se o outro (DUSSEL, 1993).

${ }^{9}$ A valorização das fontes orais se deu com o advento da renovação de métodos e perspectivas da análise histórica, a partir dos trabalhos de pesquisa do grupo de estudiosos conhecidos como Escola dos Annales. A utilização dessas novas fontes foi possível devido à incorporação de inventos tecnológicos ao ofício do historiador, como o gravador e o computador, por exemplo. A história oral passou a ser utilizada para informar sobre a existência do documento tradicional ou modificar sua leitura. Thompson vinculou a valorização das fontes orais à ascensão ao poder de grupos ou classes sociais sem uma história escrita, além da necessidade que sentiram alguns historiadores de registrarem lutas clandestinas de grupos que não documentaram suas ações, como perseguidos políticos, por exemplo (LOURO, 1990).

${ }^{10}$ Essa família constituiu-se em exceção, pois nesse primeiro momento, grande parte dos migrantes viviam nas fazendas, ir a cidade fazia parte do seu lazer: "Depois de um certo tempo, quando as famílias nordestinas 
já estavam mais habituadas à vida na região, em muitas fazendas criou-se o hábito de ir à cidade aos sábados fazer compras. (...) a oportunidade para ir à cidade acabava se transformando num passeio." (SILVA, 1997, p.95) E ainda: "O trabalhador nordestino, quando recebia seu salário e quando tinha a chance de ir à cidade, realizava o seu sonho de consumo." (SILVA, 1997, p.31)

${ }^{11} \mathrm{O}$ estranhamento aos migrantes sírio-libaneses aconteceu de outra forma: "No entanto foram recebidos e aceitos mais facilmente pela sociedade do que os nordestinos. Os Sírio-Libaneses eram comerciantes e empresários, que chegavam para movimentar o comércio da cidade, ao passo que os nordestinos traziam a mão-de-obra, o trabalho braçal, historicamente desvalorizado, na nossa cultura, e relegado a pessoas de condição inferior”. (SILVA, 1997, p.112)

${ }^{12}$ Em alguns depoimentos é possível apontar a discriminação do aluno nordestino por parte de professores que reproduziam estereótipos negativos como o de povo violento. "Porque quando eu fiz a quarta série na fazenda com o professor José Gonçalves, ele tinha pavor de nordestino. (...) tinha tanto preconceito com nós quando fazia quarta série, que separava nós. Que falava: 'Eu quero nortista tudo naquele canto! Que esse povo não presta! Tudo naquele canto! Que vão brigar e vão judiar!' E punha nós tudo num canto. Nós sentado tudo num canto desconfiado com as cabeça baixa. Você acredita? (risos) Aí nós ficava lá por isso. Aí os menino saía pro recreio, depois que os menino saía é que nós saía., pra nós num brigar. É mole?" (Entrevista F, abril/2010)

${ }^{13}$ A precariedade estava presente em todo o sistema de ensino desde as escolas mais antigas até as recémcriadas, nessa matéria se denunciava a falta de carteiras e os alunos assistiam as aulas sentados no chão: "Ainda sem mobiliário o Grupo Escolar Senador Camilo Chaves" (Folha de Ituiutaba, 25-fev-1956)

${ }^{14}$ A generalização do ensino e sua organização mais democrática é uma forma de garantir o desenvolvimento da sociedade, o crescimento econômico, a evolução dos costumes, além de se construir nova cultura de participação política. Por isso mesmo, o esforço pela criação de uma nova cultura local, com apelo multiculturalista, dado as peculiaridades da constituição social da cidade (RIBEIRO, 1993).

15 Essa é uma das depoentes que desde muito pequena precisou enfrentar trabalho pesado para colaborar com a manutenção da família. Apesar disso, sempre estudou e terminou a graduação. Hoje está aposentada da profissão de professora de matemática: "Quando eu comecei a trabalhar eu tinha sete anos. (...)eu era menina, mas como eu era muito ativa, era eu e meu irmão. (...)Nós levantava de quatro horas, ia na carreira pros cavalos. Punha os cavalos pra dentro, tratava dos porcos, ia buscar água. Por quê? Porque a cisterna, a água fica barrenta e secava. Aí nós... Nossa casa era a primeira a ser abastecida. Quando era cinco e meia, nós já tava tudo com os latão, tudo que nós tinha, cheio d'agua, que era pra poder nós... Aí depois dessa hora, nós ia trabalhar, ajudar, puxar cavalo, pra levar a comida na roça. As bacia de comida... Punha as rodias, que a gente fazia de pano. (...) Nós levava as comida e vinha na carreira pra nós almoçar, tomar banho e ir pra escola. Porque três horas nós tinha que sair da escola e levar a janta. Tá bom? E ainda pra chegar e ser xingado de nortista, ser achincalhado?" (Entrevista F, abril/2010)

Artigo recebido em: 23/09/2010

Aprovado em: 17/12/2010 